\title{
Reduced Nicotinamide Adenine Dinucleotide-Selective Stimulation of Inositol 1,4,5-Trisphosphate Receptors Mediates Hypoxic Mobilization of Calcium
}

\author{
Adam I. Kaplin, ${ }^{1}$ Solomon H. Snyder, ${ }^{1,2}$ and David J. Linden ${ }^{1}$ \\ 1 Department of Neuroscience, and 2Departments of Pharmacology and Molecular Sciences, and Psychiatry, Johns \\ Hopkins University School of Medicine, Baltimore, Maryland 21205
}

\begin{abstract}
To evaluate the relationship of inositol 1,4,5-trisphosphate $\left(\mathrm{IP}_{3}\right)$ receptor-mediated signal transduction and cellular energy dynamics, we have characterized effects of nucleotides on $\mathbb{I P}_{3}$ receptor $\left(\mathrm{IP}_{3} \mathrm{R}\right)$-mediated calcium $\left(\mathrm{Ca}^{2+}\right)$ flux in purified $\mathrm{IP}_{3}$ receptors reconstituted in lipid vesicles $\left(\mathrm{IP}_{3} \mathrm{RV}\right)$ and examined hypoxia-induced augmentation of intracellular $\mathrm{Ca}^{2}$ in intact cells. Reduced nicotinamide adenine dinucleotide (NADH) increases $I_{3}$-mediated $\mathrm{Ca}^{2+}$ flux in $\mathrm{IP}_{3} \mathrm{RV}$. This effect is highly specific for NADH. Hypoxia elicited by brief exposure of nerve growth factor-differentiated PC12 cells or cerebellar Purkinje cells to cyanide elicits rapid increases in internal $\left[\mathrm{Ca}^{2+}\right]$, which derives from $\mathrm{IP}_{3}$-sensitive stores. Blockade of this effect by
\end{abstract}

2-deoxyglucose and inhibition of glyceraldehyde-3-phosphate dehydrogenase implicates enhanced glycolytic production of $\mathrm{NADH}$ in the $\mathrm{Ca}^{2+}$ stimulation. Internal $\left[\mathrm{Ca}^{2+}\right]$ is markedly and specifically increased by direct intracellular injection of NADH, and this effect is blocked by heparin, further implicating $I P_{3} R$ stores. These findings indicate that direct regulation of $\mathrm{IP}_{3} \mathrm{R}$ by $\mathrm{NADH}$ is responsible for elevated cytoplasmic $\left[\mathrm{Ca}^{2}{ }^{2}\right]$ occurring in the earliest phase of hypoxia. This link of $\mathrm{IP}_{3} \mathrm{R}$ activity with cellular energy dynamics may be relevant to both hypoxic damage and metabolic regulation of $\mathrm{IP}_{3}$ signaling processes.

Key words: $\mathrm{Ca}^{2+}$; $\mathrm{NADH}$; hypoxia; signal transduction; inositol-1,4,5-trisphosphate receptor; metabolism
The role of the inositol 1,4,5-trisphosphate receptor $\left(\mathrm{IP}_{3} \mathrm{R}\right)$ in mobilizing calcium from internal stores in response to receptorcoupled signal transduction is well established (Berridge, 1993). The resultant rise in cytosolic calcium $\left(\mathrm{Ca}^{2+}{ }_{i}\right)$ serves as an intracellular second messenger activating diverse cellular processes. Recent evidence suggests that $\mathrm{IP}_{3} \mathrm{Rs}$ are responsive to alterations in cellular energy dynamics, and, conversely, that $\mathrm{Ca}^{2+}$ released by $\mathrm{IP}_{3} \mathrm{R}$ activation modulates mitochondrial function. Rizzuto et al. (1993) showed that $\mathrm{IP}_{3}$ can relcasc $\mathrm{Ca}^{2+}$ in close proximity to mitochondria, markedly elevating mitochondrial $\mathrm{Ca}^{2+}$ levels. Although it was initially believed that mitochondria merely buffer $\mathrm{Ca}^{2+}{ }_{\mathrm{i}}$ (Becker et al., 1980), recent studies indicate that $\mathrm{Ca}^{2+}$ is an effector of mitochondrial function, acting at multiple sites to increase mitochondrial respiration and thereby stimulate ATP formation (McCormack et al., 1990). Mitochondrial function alters in response to mobilization of $\mathrm{Ca}^{2+}$ from $\mathrm{IP}_{3}$-sensitive stores in numerous cell types (Duchen et al., 1993; Loew et al., 1994; Sheu and Jou, 1994). Taken together, these studies provide a potential link between $I_{3} R$-mediated signal transduction and energy production.

Received Aug. 25, 1995; revised Dec. 14, 1995; accepted Dec. 18, 1995.

This research was supported by United States Public Health Service training grant GM-(07309 to A.I.K.; by United States Public Health Service Grants DA-00266, MH-18501, and Research Scientist Award DA-001074, and grants of the W. M. Keck and Stanley Foundations to S.H.S.; and by United States Public Health Service Grant MH-51106, an Altred P. Sloan Research Fellowship, a McKnight scholarship, a National Alliance for Research on Schizophrenia and Depression Young Investigator Award, and a Klingenstein Fellowship to D.J.L.

We thank Lynda Hester and Dorit Gurfel for their superb technical assistance and Christopher Ferris for his thoughtful discussions. We thank Akira Endo for his generous gift of koningic acid, and Peter L. Pedersen for many stimulating conversations and for his instructive comments on our manuscript.

Correspondence should be addressed to David J. Linden, Department of Neuroscience, Johns Hopkins University School of Medicinc, Baltimore, MD 2120 s. Copyright $\odot 1996$ Socicty for Neuroscience $0270-6474 / 96 / 162002-10 \$ 05.00 / 0$
Conversely, metabolites generated during energy production may influence $\mathrm{IP}_{3} \mathrm{R}$-mediated $\mathrm{Ca}^{2+}$ dynamics. ATP stimulates $\mathrm{Ca}^{2+}$ flux from purified $\mathrm{IP}_{3} \mathrm{R}$ reconstituted in lipid vesicles $\left(\mathrm{IP}_{3} \mathrm{RV}\right)$ (Ferris et al., 1990), from $\mathrm{IP}_{3} \mathrm{R}$ incorporated into lipid bilayers (Bezprozvanny and Ehrlich, 1993), and from $\mathrm{IP}_{3}$-sensitive $\mathrm{Ca}^{2+}$ stores in permeabilized cells (Iino, 1991). The stimulation by ATP is selective for adenine nucleotides and is much greater with ATP than with ADP or AMP (Ferris et al., 1990).

ATP is not the only indicator of the energy status of a cell. Depletion of cellular energy reserves leads to the accumulation of cytoplasmic reduced nicotinamide adenine dinucleotide (NADH) (Veech et al., 1970). This may be particularly relevant in pathological conditions such as hypoxia. Hypoxia decreases mitochondrial respiration by inhibiting the terminal step in the electron transport chain. Perturbations in cellular energy production in hypoxia provoke a rapid rise in $\mathrm{Ca}^{2+}{ }_{i}$ in most cells, which if sustained may lead to cell death (Schanne et al., 1979; Siesjo, 1981; Cervos-Navarro and Diemer, 1991). A substantial component of this $\mathrm{Ca}^{2+}$ derives from intracellular stores (Krnjevic and Xu, 1989; Biscoe and Duchen, 1990; Duchen et al., 1990; Silver and Erecinska, 1990; Dubinsky and Rothman, 1991; Hasham et al., 1991; Latha et al., 1994). Recently it was shown that in CA1 pyramidal neurons maintained in a hippocampal slice preparation, the induction of anoxia resulted in an intracellular $\mathrm{Ca}^{2+}$ release, predominantly from an $\mathrm{IP}_{3}-$ sensitive store (Belousov et al., 1995). The mechanisms that mediated this release, however, remained elusive. Hypoxic insults also increase cytoplasmic NADH levels as a result of enhanced glycolysis (Duffy et al., 1972; Ozaki et al., 1988; Yager et al., 1991; Behar, 1993).

We now demonstrate that NADII selectively stimulates the release of $\mathrm{Ca}^{2+}$ mediated by $\mathrm{IP}_{3} \mathrm{R}$ both in purified reconstituted 
Table 1. $\Lambda T P$ and NADH increase $\mathrm{Ca}^{2+}$ flux of $\mathrm{IP}_{3} \mathrm{RV}$ in the presence of a fixed concentration of $\mathrm{IP}_{3}$

\begin{tabular}{lccl}
{$\left[\begin{array}{l}{\left[\mathrm{IP}_{3}\right]} \\
(\mathrm{nM})\end{array}\right.$} & $\begin{array}{l}{[\mathrm{ATP}]} \\
(\mu \mathrm{M})\end{array}$ & $\begin{array}{l}{[\mathrm{NADH}]} \\
(\mu \mathrm{M})\end{array}$ & $\begin{array}{l}\text { Stimulation of } \\
\mathrm{Ca}^{2+} \text { flux }(\%)\end{array}$ \\
\hline 10 & 50 & 0 & $39 \pm 3$ \\
10 & 0 & 300 & $38 \pm 5$ \\
40 & 50 & 0 & $30+2$ \\
40 & 0 & 300 & $29 \pm 4$
\end{tabular}

$\mathrm{IP}_{3} \mathrm{RVs}$ were preincubated for $30 \mathrm{sec}$ in the presence of ${ }^{45} \mathrm{Ca}^{2+}$ and $\mathrm{IP}_{3}$ at the concentrations indicated. After this incubation, ATP or NADH was added with a sufficient amount of ${ }_{\mathrm{IP}} \mathrm{t}_{3}$ to maintain $\left[\mathrm{IP}_{3}\right]$ at the indicated value. Flux was allowed to proceed for an additional $30 \mathrm{sec}$, followed by processing of the vesicles to determine the total amount of $\mathrm{Ca}^{2+}$ flux obtained. Data are expressed as the percentage stimulation of specific $\mathrm{Ca}^{2+}$ flux seen in the presence of each nucleotide relative to the specific flux obtained in their absence Data are presented as mean $+\mathrm{SEM}_{2} n=$ 2. This experiment was repeated three times with the same results.

receptor preparations and in intact cells. Hypoxic mobilization of $\mathrm{Ca}^{2+}$ reflects $\mathrm{NADH}$ stimulation of $\mathrm{IP}_{3} \mathrm{R}$ activity.

\section{MATERIALS AND METHODS}

Materials. $\left[{ }^{3} \mathrm{H}\right] I \mathrm{I}_{3}$ and ${ }^{4.5} \mathrm{Ca}^{2+}$ were obtained from Du Pont-NEN (Boston, MA), D-myo-I $(1,4,5) \mathrm{P}_{3}$, hexapotassium salt from LC Laboratorics (Woburn, MA), and concanavalin A-sepharose from Pharmacia LKB Biotechnology (Piscataway, NJ). Phospholipids for reconstitution were obtained from Avanti Polar Lipids (Birmingham, AL), and Fura-2 from Molecular Probes (Eugene, OR). Koningic acid was the generous gift of Akira Endo. All other reagents were from Sigma (St. Louis, MO).

Purified and reconstituted $I P_{3}$ Rs. $\mathrm{IP}_{3}$ Rs were purified from adult male Sprague-Dawley rat ccrebellum and reconstituted into lipid vesicles as described (Ferris et al., 1989), by a two-step affinity-chromatography procedure using sequential heparin-agarose and concanavalin A-sepharose columns. After purification to apparent homogeneity, detergent-solubilizcd receptor protein was mixed with sonicated lipids, and the mixture was dialyzed to effect detergent removal and vesicle formation.

Stock ATP, pyridine nucleotide, sodium lactate, and sodium pyruvate solutions were prepared fresh in NKT buffer $(50 \mathrm{~mm} \mathrm{NaCl}, 50 \mathrm{mM} \mathrm{KCl}$, and $20 \mathrm{~mm}$ Tris-Cl, $\mathrm{pH} 7.4$ ), and the $\mathrm{pH}$ was adjusted to 7.4 with $\mathrm{NaOH}$ when necessary. Sodium cyanide solutions, also prepared fresh in NKT buffer, were adjusted to $\mathrm{pH} 7.4$ with $\mathrm{HCl}$.

Reconstituted proteoliposomes were assayed for $\mathrm{IP}_{3}$-stimulated ${ }^{45} \mathrm{Ca}^{2+}$ flux as described (Ferris et al., 1989). After preincubation under various conditions, vesicles were incubated in the presence of $2 \mu \mathrm{Ci}^{45} \mathrm{Ca}^{2+}$ with or without $\mathrm{IP}_{3}$. Unless otherwise indicated (Table 1), all $\mathrm{Ca}^{2+}$ flux incubations were for $15 \mathrm{sec}$ at room temperature. The flux reaction was stopped by the addition of excess buffer containing unlabeled divalent cations and heparin. The vesicle/buffer mixture was passed over a cationexchange column (Dowex 50W, Sigma), and the intravesicular ${ }^{45} \mathrm{Ca}^{2+}$ content was measured by scintillation spectrometry. Specific $\mathrm{Ca}^{2+}$ flux was calculated as the total flux seen with $\mathrm{IP}_{3}$ ( \pm nucleotides) minus the blank flux obtained in the absence of $\mathrm{IP}_{3}$. Lactate, pyruvate, cyanide, and any of the nucleotides that were used did not affect the blank. $\left[{ }^{3} \mathrm{H}\right] \mathrm{IP}_{3^{-}}$ binding was assayed by precipitation of $\mathrm{IP}_{3} \mathrm{RV}$ with polyethylene glycol, using gamma globulin as carrier protein, as described (Ferris et al., 1989).

$\mathrm{Ca}^{2+}$ imaging. $\mathrm{PCl} 2$ cells were grown on polylysine-coated glass coverslips and differentiated with $50 \mathrm{ng} / \mathrm{ml}$ nerve growth factor (NGF) for 4-6 d before use. During $\mathrm{Ca}^{2+}$-imaging experiments, PC12 cells and embryonic mouse Purkinje cells (Linden et al., 1991) were bathed in a solution that contained $\mathrm{NaCl}(140 \mathrm{~mm}), \mathrm{KCl}(5 \mathrm{~mm})$, EGTA $(0.2 \mathrm{~mm})$ $\mathrm{MgCl}_{2}(0.8 \mathrm{~mm})$, HEPES $(10 \mathrm{~mm})$, glucose $(10 \mathrm{~mm})$, tetrodotoxin $(0.5$ $\mu \mathrm{M})$, and picrotoxin $(0.1 \mathrm{~mm})$, adjusted to $\mathrm{pH} 7.35$ with $\mathrm{NaOH}$. This solution flowed at a rate of $\sim 0.5 \mathrm{ml} / \mathrm{min}$ through a bath of $1.0 \mathrm{ml}$ volume. Fura-2 dye was introduced via a whole-cell patch pipette. Patch pipettes were pulled from N51A glass and polished on a microforge to yield a resistance of 3-6 $\mathrm{M} \Omega$. They contained $\mathrm{KCl}(100 \mathrm{mM})$, HEPES $(10 \mathrm{~mm})$, and Fura-2, $\mathrm{K}_{5}$-salt $(10 \mathrm{~mm})$, adjusted to $\mathrm{pH} 7.1$ with $\mathrm{KOH}$. For loading, a gigaohm seal was formed under voltage-clamp conditions, and a command potential of $-70 \mathrm{mV}$ was applied. After membrane rupture, loading of the cell with dye was monitored by fluorescence at $384 \mathrm{~nm}$, as described below. When sufficient dye perfusion had occurred in PC12 cells, the patch electrode was slowly retracted axially to allow the cell membrane to reseal. The cells were then allowed to equilibrate for $20 \mathrm{~min}$ before stimulation. Purkinje cells were loaded with a solution containing $\mathrm{KCl}(140 \mathrm{~mm})$, HEPES $(10 \mathrm{~mm})$, and Fura-2, $\mathrm{K}_{3}$-salt $(200 \mu \mathrm{M})$ and then stimulated with the loading electrode attached after dye perfusion.

Imaging of intracellular free $\mathrm{Ca}^{2+}$ was accomplished by measuring the background-corrected fuorescence ratio at 337 and $384 \mathrm{~nm}$ excilation, using a cooled CCD camera system. Illumination at $337 \mathrm{~nm}$ was provided by a pulsed nitrogen laser operating at $20 \mathrm{~Hz}$, and $384 \mathrm{~nm}$ was provided by a separate nitrogen-pumped laser using the dye Exalite 384 (Laser Science, Woburn, MA). This light was passed through a quartz fiberoptic $\mathrm{Y}$-conduit to the epifluorescence train of a Zeiss Axiovert 100 equipped with a $40 \times 1.3$ NA oil-immersion objective. Emission at $505 \mathrm{~nm}$ was passed through a dichroic mirror and was focused on the chip (Thompson 7883) of a slow-scan, cooled CCD camera (Photometrics CH250, Tucson, AZ). Exposure times were $400 \mathrm{msec}$ per single wavelength image. Digitized images were acquired to disk using custom software (kindly provided by Dr. D. W. Tank, AT\&T Bell Labs). Free $\mathrm{Ca}^{2+}$ concentration was derived from the F337/F384 ratio measurements, using the standard relationship outlined by Grynkiewicz et al. (1985), incorporating a viscosity correction factor of 0.85 , the latter derived from comparisons between calibrations made in internal saline and those made in the cytoplasm of ionomycin-permeabilized Purkinje cells. Background fluorescence in unloaded cells wals $<1 \%$ of the resting signal at either excitation wavelength.

For stimulating PC12 cells, pressure-cjection pipettes (1-2 $\mu \mathrm{m}$ tip diameter) were filled with various solutions and were positioned $\sim 100$ $\mu \mathrm{m}$ away from the cell soma. Ejection was accomplished by applying pressure pulses of 4-6 psi. This configuration allowed us to apply significant concentrations of test solutions to single cells or, occasionally, to several cells positioned closely together. To produce a transient oxidative stress, external saline supplemented with $\mathrm{NaCN}(2 \mathrm{~mm})$ was ejected for 10 sec. To activate ryanodine receptor-gated $\mathrm{Ca}^{2}+$ stores, external saline with $\mathrm{NaCl}$ reduced to $130 \mathrm{~mm}$ and supplemented with caffeine $(20 \mathrm{~mm})$ was ejected for $10 \mathrm{sec}$. Heparin $(100 \mu \mathrm{g} / \mathrm{ml})$, de- $N$-sulfated heparin $(100$ $\mu \mathrm{g} / \mathrm{ml})$, ruthenium red $(10 \mu \mathrm{M})$, and koningic acid $(50 \mu \mathrm{M})$ were included in the internal saline used for Fura-2 loading. Thapsigargin $(1 \mu \mathrm{M})$, U73122 $(5 \mu \mathrm{M})$, or iodoacetate $(500 \mu \mathrm{M})$ were applied in the bath starting immediately after Fura-2 loading, as was an external saline in which glucose $(10 \mathrm{mM})$ was replaced with 2-deoxyglucose $(10 \mathrm{~mm})$.

In one set of experiments (see Fig. 6), PC12 cells were loaded with Fura-2/AM, washed, and then perfused internally with various nucleotides dissolved in a solution containing $\mathrm{KCL}(140 \mathrm{mM})$ and HFPFS (10 $\mathrm{mM}$ ). These compounds were $\beta-\mathrm{NADH}, \mathrm{Na}_{2}$ salt, $\beta$-reduced nicotinamide adenine dinucleotide phosphate ( $\beta$-NADPH) $\mathrm{Na}_{4}$-salt, and ATP, $\mathrm{K}_{2}$ salt.

All experiments were conducted at ambient room temperature.

\section{RESULTS}

\section{NADH stimulates $\mathrm{Ca}^{2+}$ release from purified and reconstituted $I P_{3} R$}

In $\mathrm{IP}_{3} \mathrm{RV}, 50 \mu \mathrm{M}$ ATP maximally stimulates $\mathrm{Ca}^{2+}$ flux (Fig. $1 A$ ). At higher concentrations of ATP, stimulation of $\mathrm{Ca}^{2+}$ flux diminishes so that at $1 \mathrm{~mm}$ ATP, $\mathrm{Ca}^{2}$ flux is close to control values. $\mathrm{NADH}$ also stimulates $\mathrm{Ca}^{2+}$ flux with maximal effects at $300 \mu \mathrm{M}$ and half-maximal stimulation at $30 \mu \mathrm{M}$. NADH $(300 \mu \mathrm{M})$ increases $\mathrm{Ca}^{2+}$ flux at all [ $\mathrm{IP}_{3}$ ], resembling the effects of ATP $(50 \mu \mathrm{M})$ (Fig. $1 B$ ). Neither NADH nor ATP augment $\mathrm{Ca}^{2+}$ flux in the absence of $\mathrm{IP}_{3}$ (data not shown). NADH and ATP seem to act at the same site, as their effects are not additive (Fig. 1C). Scatchard analysis of $\left[{ }^{3} \mathrm{H}\right] \mathrm{IP}_{3}$ binding to $\mathrm{IP}_{3} \mathrm{RV}$ reveals no change in either $K_{\mathrm{d}}$ or $B_{\max }$ in the presence of $50 \mu \mathrm{M}$ ATP or $300 \mu \mathrm{M}$ $\mathrm{NADH}\left[K_{\mathrm{d}}=20 \pm 4.1 \mathrm{nM}\right.$ (mean $\perp \mathrm{SEM}, n=5$ ), $20 \pm 1.6 \mathrm{~nm}$, $19 \pm 3.5 \mathrm{nM}$, and $B_{\max }=2.0 \pm 0.2 \mathrm{nM}, 2.1 \pm 0.1 \mathrm{nM}$, and $2.0 \pm$ $0.2 \mathrm{nM}$ under control conditions, with ATP or with NADH, respectively].

The enhancement of $\mathrm{Ca}^{2+}$ flux by NADH is strikingly selective (Fig. 2). Although $10 \mu \mathrm{M}$ NADH stimulates $\mathrm{Ca}^{2+}$ flux by $>30 \%$, a 30 -fold higher concentration of NAD is required to attain the same effect. Maximal stimulation of $\mathrm{Ca}^{2+}$ flux by NAD is only $20 \%$ of that elicited by NADH. NADP and NADPH fail to 

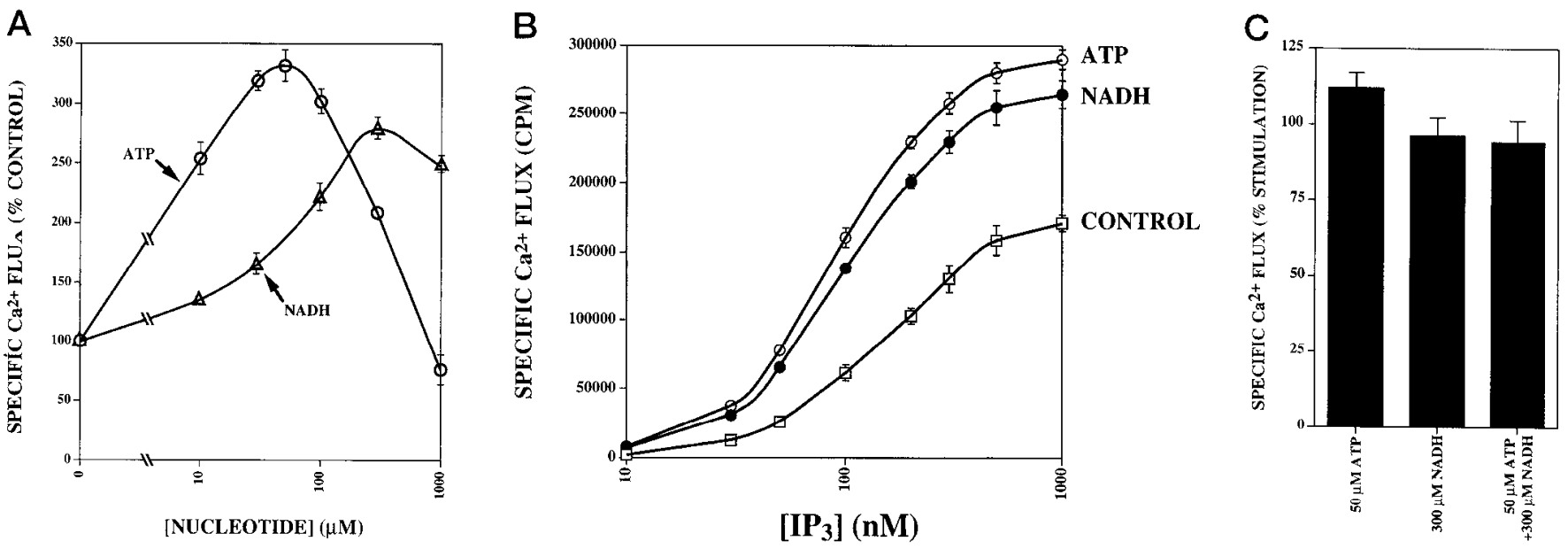

Figure 1. Stimulation of purified $\mathrm{IP}_{3} \mathrm{R}$ activity by NADH and ATP. $A$, Concentration-response relationships for the effects of NADH and ATP on $\mathrm{IP}_{3}$-mediated $\mathrm{Ca}^{2+}$ flux. $\mathrm{Ca}^{2+}$ flux was determined for $\mathrm{IP}_{3} \mathrm{RVs}$ incubated with various concentrations of NADH $(\wedge)$ or ATP $(O)$ in the presence of 40 nM IP ${ }_{3}$. Data are presented as a percentage of the specific $\mathrm{Ca}^{2}$ flux obtained in the presence of $40 \mathrm{~nm} \mathrm{IP}$ alone (calculated as described in Materials and Methods). Error bars show SEM, $n=2$. Points without error bars represent data in which SEM was less than the size of the plot synibol. This experiment was repeated four times with separate batches of $I P_{3} R V$ yielding the same pattern of concentration-response. For each batch, the response was highly reproducible, as exemplified by the data shown in the figure. Between batches, however, the magnitude of the stimulation varied, giving a maximal stimulation by NADH and ATP that ranged from $170 \%$ and $190 \%$ (expressed as percentage control using 40 nM IP alone) to $280 \%$ and $330 \%$, respectively. $B$, Effects of NADH and ATP on $\mathrm{IP}_{3}$ concentration-response. The $\mathrm{Ca}^{2+}$ flux of $\mathrm{IP}_{3} \mathrm{RVs}$ was determined in the absence of nucleotides (control, $\square$ ) or in the presence of $300 \mu \mathrm{M} \mathrm{NADH}(\bullet)$ or $50 \mu \mathrm{M}$ ATP $(O), n=2$. This experiment was repeated three times with the same results. $C$, Effects of NADH and ATP on $\mathrm{IP}_{3}$-mediated $\mathrm{Ca}^{2+}$ flux are not additive. Data are presented as the percentage stimulation of specific $\mathrm{Ca}^{2+}$ flux obtained in the presence of $100 \mathrm{~nm} \mathrm{IP}_{3}$ alone $(n=2)$. This experiment was repeated five times with the same results.

stimulate $\mathrm{Ca}^{2+}$ flux at any concentration. Instead, they exert an inhibitory effect, with NADPH being more potent and producing a larger maximal effect than NADP.

Basal endogenous $\mathrm{IP}_{3}$ concentrations are in the micromolar range (Bredt et al., 1989), which are sufficient to cause maximal $\mathrm{IP}_{3}$ enhancement of $\mathrm{Ca}^{2+}$ flux as assessed in vitro (Fig. 1B). Assuming a roughly similar potency in vivo, this suggests that there are inhibitory influences on the $\mathrm{IP}_{3} \mathrm{R}$ responsiveness in the

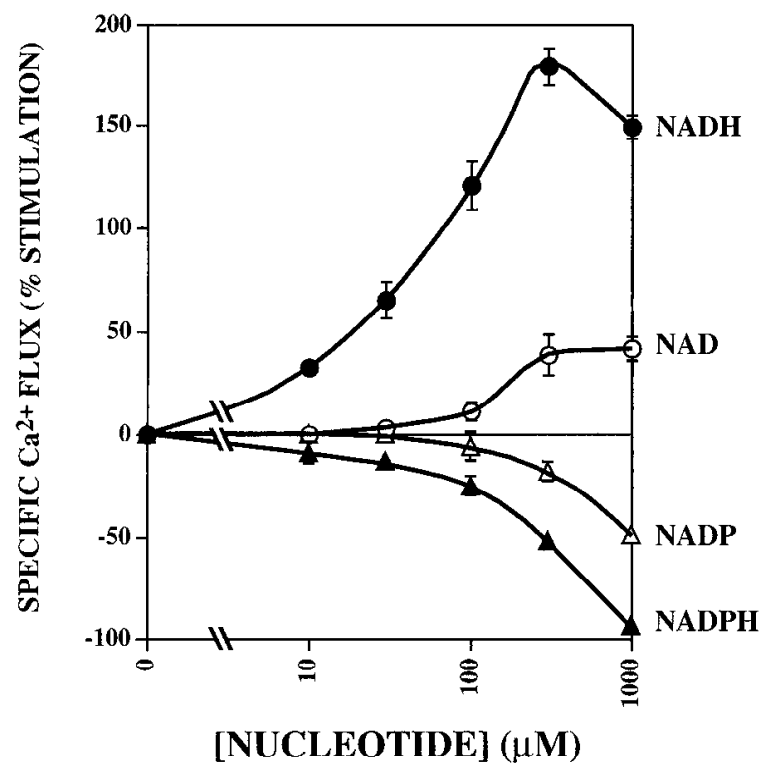

Figure 2. Specificity of the effects of NADH on $\mathrm{IP}_{3}$-mediated $\mathrm{Ca}^{2+}$ flux. $\mathrm{Ca}^{2+}$ flux was determined for $\mathrm{IP}_{3} \mathrm{RVs}$ incubated with various concentrations of pyridine nucleotides in the presence of $40 \mathrm{nM} \mathrm{IP}_{3}$. Data are presented as the percentage stimulation of specific $\mathrm{Ca}^{2+}$ flux obtained in the presence of $40 \mathrm{nM} \mathrm{IP}_{3}$ alone $(n=2)$. This experiment was repeated four times with the same results. cell. Moreover, at some intracellular loci, $\mathrm{Ca}^{2+}$ release by $\mathrm{IP}_{3} \mathrm{R}$ may not be determined by changes in $\mathrm{IP}_{3}$ concentration, which is present in abundance, but rather by an alternate stimulatory mechanism, such as alterations in levels of ATP or NADH. To approximate this situation, we preincubated $\mathrm{IP}_{3}$ and ${ }^{45} \mathrm{Ca}^{2+}$ with IP 3 RV for $30 \mathrm{sec}$ and then added ATP or N $\Lambda$ DH (Table 1). Because we do not know the in vivo mechanisms that presumably inhibit $\mathrm{IP}_{3} \mathrm{R}$ responsiveness but we do know that $\mathrm{IP}_{3} \mathrm{Rs}$ are not maximally stimulated by basal levels of $\mathrm{IP}_{3}$, we preincubated with $\left[\mathrm{IP}_{3}\right]$ that would produce a submaximal response in vitro. The design of this experiment is complicated by the fact that exposure of $\mathrm{IP}_{3} \mathrm{RV}$ to various concentrations of $\mathrm{IP}_{3}$ results in a biphasic stimulation of $\mathrm{Ca}^{2+}$ flux, which is rapid for the first $10 \mathrm{sec}$ and then slows (Ferris et al., 1992). This is a reflection of the quantal nature of $\mathrm{IP}_{3} \mathrm{R}$ activation, a property intrinsic to the purified receptor. Nevertheless, under the conditions employed in Table 1 , both ATP and NADH still provide substantial increases in $\mathrm{Ca}^{2+}$ flux in the continued presence of a fixed concentration of $\mathrm{IP}_{3}$ and $\mathrm{Ca}^{2+}$. The absolute magnitude of the stimulation achieved under these conditions is less than that achieved in Figure 1, suggesting that the nucleotides exert more dramatic effects on the fast phase of $\mathrm{Ca}^{2+}$ flux from $\mathrm{IP}_{3} \mathrm{RV}$. The results depicted in Table 1 demonstrate that changes in cytoplasmic concentrations of ATP or $\mathrm{NADH}$ could result in $\mathrm{Ca}^{2+}$ efflux from $\mathrm{IP}_{3} \mathrm{R}$ stores in the absence of increases in $\mathrm{IP}_{3}$.

\section{Chemical hypoxia mobilizes $\mathrm{Ca}^{2+}$ from $\mathrm{IP}_{3}$-sensitive intracellular stores via NADH production}

The strikingly selective stimulation of $\mathrm{IP}_{3}$-mediated $\mathrm{Ca}^{2+}$ flux by NADH suggests a physiological role. To explore this possibility, we sought a system in which NADH levels increase in response to physiological perturbation. Cytoplasmic stores of $\mathrm{NADH}$, the pool that would be exposed to $\mathrm{IP}_{3} \mathrm{R}$, increase substantially during hypoxia (Duffy et al., 1972; Ozaki et al., 1988; Yager, 1991; Lai and Behar, 1993). Moreover, increases in $\mathrm{Ca}^{2+}{ }_{i}$ after the induc- 

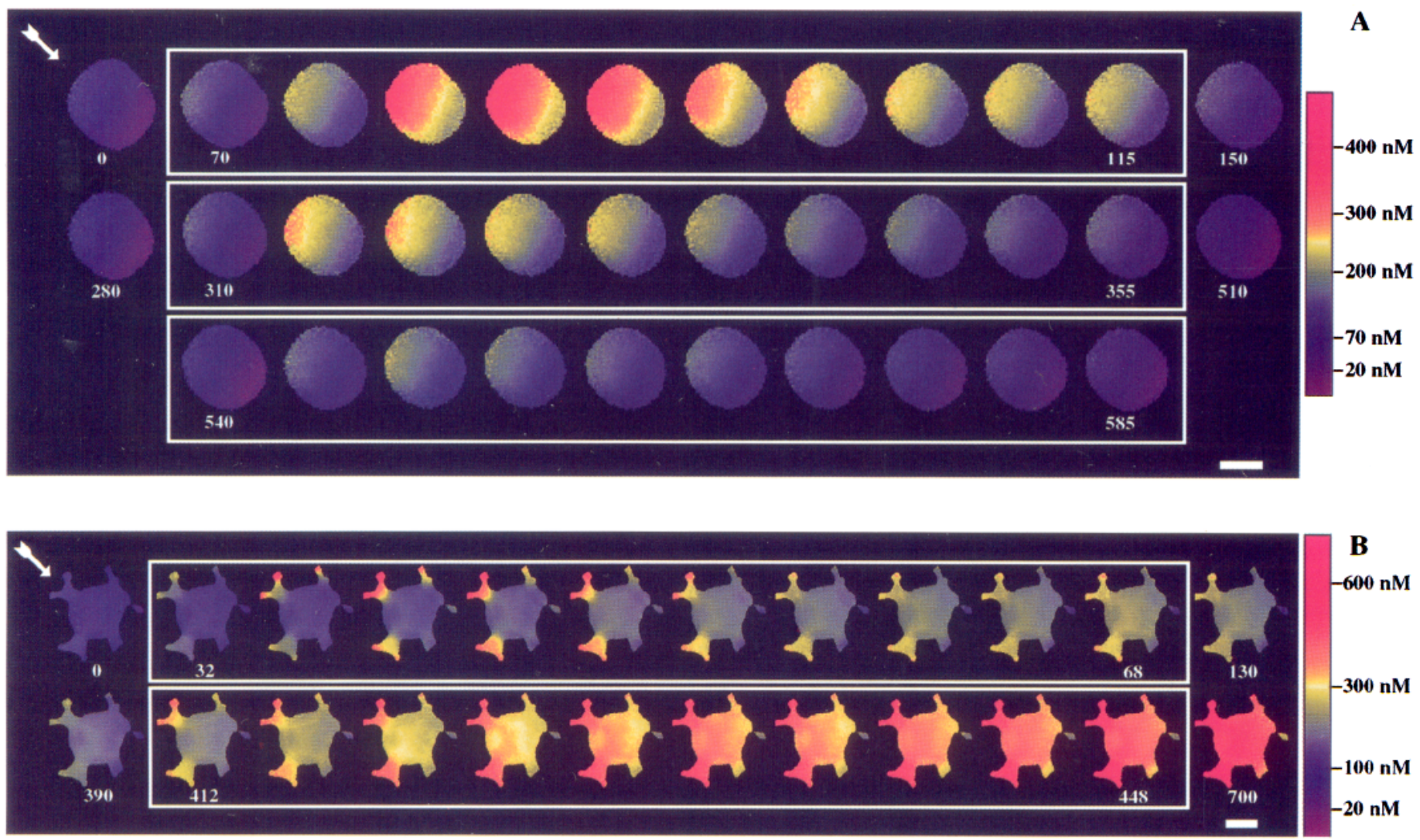

Figure 3. $\mathrm{Ca}^{2+}$ mobilization evoked by a brief hypoxic stimulus in PC12 cells as measured using Fura-2 microfluorimetry. A, The most common form of response in which successive pulses of cyanide $(2 \mathrm{~mm}, 10 \mathrm{sec})$ give rise to decremental mobilizations. Each horizontal row is a Ca ${ }^{2+}$ map of the same cell before, during, and after a cyanide stimulus. Images within the rectangular box begin with the cyanide pulse and proceed at 5 sec intervals. Total elapsed time in seconds is indicated. The arrow represents the position of the cyanide-containing micropressure pipette. Scale bar, $10 \mu \mathrm{m}$. $B$, A less common form of response in which the $\mathrm{Ca}^{2+}$ levels evoked by the first pulse do not return to baseline and in which the second pulse then gives rise to a persistent activation. In this case, the interval between images depicted in the horizontal box is 4 sec. Scale bar, $20 \mu \mathrm{m}$.

tion of hypoxia occur in both neuronal and non-neuronal cells (Krnjevic and Xu, 1989; Biscoe and Duchen, 1990; Duchen et al., 1990; Silver and Erecinska, 1990; Dubinsky and Rothman, 1991; Hasham et al., 1994; Latha et al., 1994). Rapid application of cyanide provides an efficient, quantifiable, and reproducible means of inducing cellular hypoxia (Albaum, 1946). Cyanide has no direct effect on the $\mathrm{IP}_{3}$-mediated $\mathrm{Ca}^{2+}$ flux of purified $\mathrm{IP}_{3} \mathrm{RV}$ [0.1 mM, $1 \mathrm{~mm}$, or $10 \mathrm{~mm}$ sodium cyanide in the presence of $1 \mu \mathrm{M}$ $\mathrm{IP}_{3}$ results in specific $\mathrm{Ca}^{2+}$ flux that is $94 \pm 3 \%$ (mean \pm SEM, $n=3), 99 \pm 0.4 \%$, or $100 \pm 4 \%$, respectively, of flux obtained in the absence of cyanide]. PC12 cells adopt a neuronal phenotype upon treatment with NGF and have been used often in studies of cyanide influences on cellular metabolism (Maduh et al., 1991; Latha et al., 1994). We measured intracellular $\mathrm{Ca}^{2+}$ in differentiated PC12 cells by ratiometric imaging of Fura-2. These experiments were conducted in $\mathrm{Ca}^{2+}$-free $0.2 \mathrm{~mm}$ EGTA external saline so that increases in $\mathrm{Ca}^{2+}{ }_{i}$ could be attributed to mobilization from internal stores rather than influx.

Micropressure application of sodium cyanide ( $2 \mathrm{~mm}$ ) for $10 \mathrm{sec}$ elicits a rapid increase in intracellular $\mathrm{Ca}^{2+}$ (Fig. 3A). The increase in $\mathrm{Ca}^{2+}{ }_{\mathrm{i}}$ begins at the side of the cell closest to the micropressure pipette, is apparent within seconds of cyanide exposure, and becomes maximal within $15 \mathrm{sec}$. At peak response, $\mathrm{Ca}^{2+}{ }_{\mathrm{i}}$ occurs in a gradient across the cell, with highest levels, $\sim 400 \mathrm{~nm}$, at the side closest to the micropressure pipette and with lowest levels, $\sim 200 \mathrm{~nm}$, at the opposite pole. $\mathrm{Ca}^{2+}{ }_{\mathrm{i}}$ decreases rapidly from peak levels during the ensuing $60 \mathrm{sec}$, reaching basal values within $3 \mathrm{~min}$ of the peak $\mathrm{Ca}^{2+}$ response. In cells that possess neurites (Fig. $3 B$ ), the pattern of $\mathrm{Ca}^{2+}{ }_{\mathrm{i}}$ enhancement is similar, with the $\mathrm{Ca}^{2+}$ wave beginning at the side of the cell closest to the micropressure pipette. Increases in $\mathrm{Ca}^{2+}$ occur first in neurites and then spread to the soma. Typically, subsequent applications of cyanide elicit a similar pattern of $\mathrm{Ca}^{2+}{ }_{\mathrm{i}}$ release, but with lower peak levels after each successive application (Fig. $3 A, 4 A)$.

Ten of 16 cells displayed a pattern of $\mathrm{Ca}^{2+}{ }_{\mathrm{i}}$ response to cyanide, as depicted in Figures $3 A$ and $4 A$, whereas two cells showed a continual increase in $\mathrm{Ca}^{2+}{ }_{\mathrm{i}}$ in response to a single dose of cyanide, which did not plateau or recover, and one cell showed no $\mathrm{Ca}^{2+}$ response to repeated cyanide pulses. In the remaining three cells, a different pattern was evident (Figs. $3 B, 4 B$ ). In these cells, after the initial peak, $\mathrm{Ca}^{2+}$ levels failed to return to baseline but recovered to below half-peak values. A subsequent administration of cyanide provoked an increase in $\mathrm{Ca}^{2+}{ }_{i}$ to levels comparable to those that followed the initial cyanide stimulus. This second $\mathrm{Ca}^{2+}{ }_{i}$ response, however, did not recover; levels remained at or above peak values for the duration of the reporting period. These variations in the temporal pattern of $\mathrm{Ca}^{2+}$ response to hypoxia did not correlate with cellular morphology. For example, one of the three cells that did not fully recover after an initial cyanide pulse lacked neurites, and 5 of the 10 cells that showed complete recovery had neurites. 

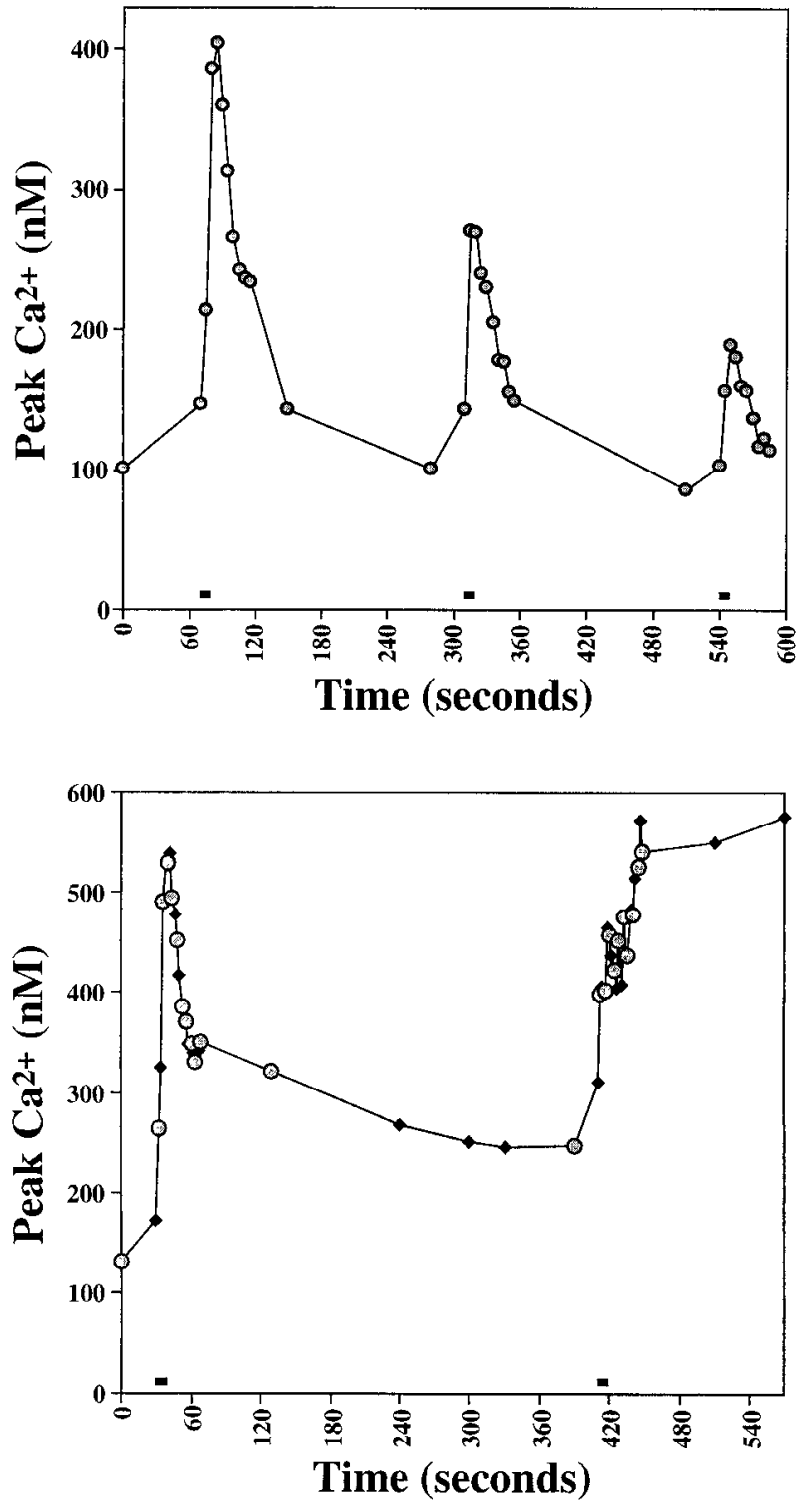

Figure 4. The time course of $\mathrm{Ca}^{2+}$ mobilization in $\mathrm{PC1} 2$ cells responding to a brief hypoxic stimulus. $A$, Representation of the peak $\mathrm{Ca}^{2+}$ level at each time point for the cell depicted in Figure $3 A . B$, The same representation for the cell depicted in Figure $3 B$. In each case, cyanide pulses are indicated by horizontal bars. Those points that have corresponding images in Figure 3 are plotted with a filled circle, whereas points without corresponding images in Figure 3 are plotted with a filled diamond.

The magnitude of $\mathrm{Ca}^{2+}$ responses in $\mathrm{PC} 12$ cells was assessed by measuring peak $\mathrm{Ca}^{2+}{ }_{i}$ levels during three consecutive $10 \mathrm{sec}$ exposures to $2 \mathrm{~mm}$ sodium cyanide and subtracting peak prestimulation $\mathrm{Ca}^{2+}{ }_{i}$ levels. Under these conditions, cyanide increases peak $\mathrm{Ca}^{21}$, levels by $204 \pm 33 \mathrm{nM}$ (mean \pm SEM, $n=13$ ) above prestimulation levels of $114 \pm 7 \mathrm{~nm}$.

Similar but more dramatic results were obtained with cmbryonic mouse Purkinje cells maintained in a dispersed culture (Fig. $5 B$ ). In a $\mathrm{Ca}^{2+}$-free $0.2 \mathrm{~mm}$ EGTA external saline solution, micropressure application of sodium cyanide $(2 \mathrm{~mm}, 10 \mathrm{sec})$ to the Purkinje cells elicits a rapid increase in peak $\mathrm{Ca}^{2+}$ iduring three successive trials of $4483 \pm 1523 \mathrm{nM}$ (mean $\pm \mathrm{SEM}, n=9$ ). Prestimulation $\mathrm{Ca}^{2+}{ }_{\mathrm{i}}$ levels in these cells were $110 \pm 10 \mathrm{~nm}$. Because the linear reporting range for Fura-2 extends only to $\sim 1000 \mathrm{~nm}$, the $\mathrm{Ca}^{2+}{ }_{1}$ achieved in this case should be considered
A

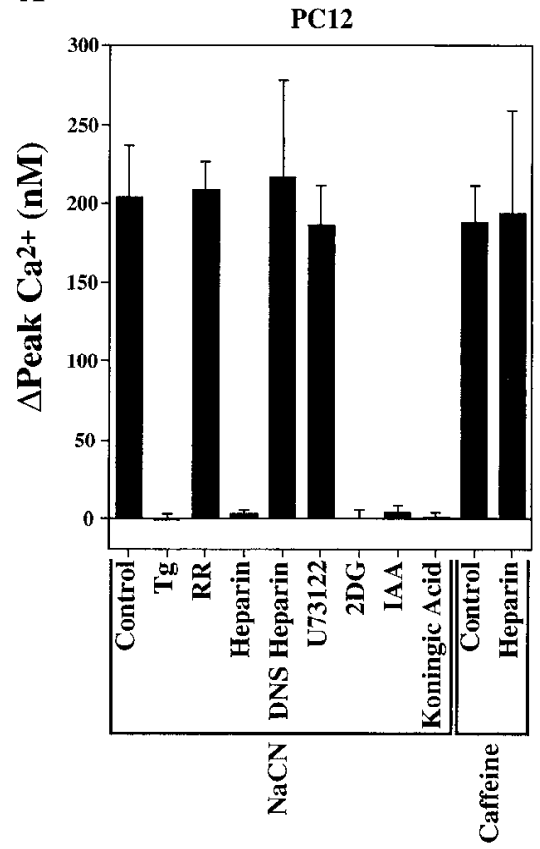

B

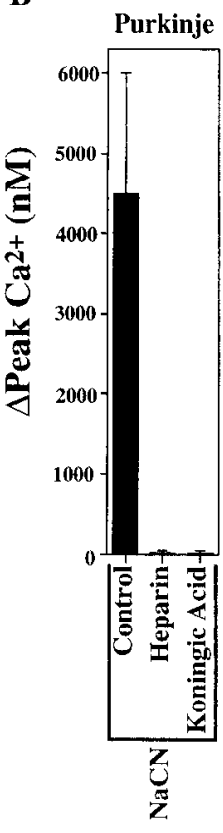

Figure 5. Pharmacological characterization of the hypoxia-induced $\mathrm{Ca}^{2}{ }^{2}$ mobilization. $\mathrm{Ca}^{2+}$ imaging was performed on PC12 cells or cerebellar Purkinje cells placed in $\mathrm{Ca}^{2}$-free saline. $A, \mathrm{Ca}^{2+}$ mobilization from $\mathrm{PCl} 2$ cells was produced by micropressure cjection of either $2 \mathrm{~mm} \mathrm{NaCN}$ for 10 sec or $20 \mathrm{~mm}$ Caffeine for $15 \mathrm{sec}$. Data are presented as the difference in the peak $\mathrm{Ca}^{2+}$ levels obtained during three pulses versus the peak $\mathrm{Ca}^{2+}$ levels present immediately before the stimulation. $\mathrm{Ca}^{2+}{ }_{\mathrm{i}}$ levels were permitted to return to baseline between each of the three pulses. Drugs were either bath-applied after the retraction of the patch pipette used to load Fura-2 into the cells or co-loaded with Fura-2 (see Materials and Methods). The drugs tested were as follows: $1 \mu \mathrm{M}$ thapsigargin ( $\mathrm{Tg}$, bathapplied), $10 \mu \mathrm{M}$ ruthenium red (RR, co-loaded), $100 \mu \mathrm{g} / \mathrm{ml}$ Heparin (co-loaded), $100 \mu \mathrm{g} / \mathrm{ml}$ de- $N$-sulfated heparin (DNS Heparin, co-loaded), $5 \mu \mathrm{M} U 73122$ (bath-applied), $10 \mathrm{~mm}$ 2-deoxyglucose (2DG, bath-applied), $0.5 \mathrm{~mm}$ iodoacetate ( $L A A$, bath-applied), or $50 \mu \mathrm{M}$ Koningic Acid (coloaded). Data are presented as the mean \pm SEM, $n=5$, with the following exceptions: $n=13$ for control conditions using $\mathrm{NaCN}$ stimulation and $n=$ 4 for $\mathrm{Tg}$ and control and heparin conditions using caffeine stimulation. Pcak $\mathrm{Ca}^{2+}$ levels present immediately before stimulation were as follows: control $111 \pm 7 \mathrm{nM}$ (mean $\pm \mathrm{SEM}, n$ as indicated above), $T_{g} 120 \pm 14 \mathrm{nM}$, $R R 124 \pm 16 \mathrm{~nm}$, Heparin $120 \pm 20 \mathrm{~nm}$, DNS Heparin $108 \pm 8 \mathrm{~nm}$, U73122 $133 \pm 4 \mathrm{~nm}, I A A 145 \pm 3 \mathrm{~nm}$, Koningic Acid $105 \pm 8$ nм. $B$, Purkinje cells were perfused with Fura- 2 with or without either $100 \mu \mathrm{g} / \mathrm{ml}$ heparin or 50 $\mu \mathrm{M}$ koningic acid. The $\mathrm{Ca}^{2+}$ mobilization was produced by micropressure application of $2 \mathrm{~mm} \mathrm{NaCN}$ for $10 \mathrm{sec}$. The response in the control condition extended into the nonlinear reporting range for Fura-2 and hence should be interpreted as being $>1000 \mathrm{~nm}$. Data are presented as in $A$, with $n=9,6$, and 5 for control, heparin, and koningic acid, respectively.

$>1000 \mathrm{~nm}$ but not explicitly quantifiable. This release took the same general spatial form as that seen in $\mathrm{PCl} 2$ cells in terms of sensitivity of processes and progression of the response from a site nearest the cyanide-containing pipette. Purkinje cells show a complete recovery of $\mathrm{Ca}^{2+}{ }_{\mathrm{i}}$ after applications of cyanide (data not shown).

We next investigated the potential sources of $\mathrm{Ca}^{2+}{ }_{i}$ released in response to cyanide stimulation. Because all experiments were conducted in a $\mathrm{Ca}^{2+}$-free medium, hypoxia-induced $\mathrm{Ca}^{2+}$ mobilization derives from internal compartments rather than from influx across the plasma membrane. Consistent with this observation, cyanide usually elicits lower peak $\mathrm{Ca}^{2+}$ levels after each successive application (Fig. 4A), indicating depletion of an intracellular $\mathrm{Ca}^{2+}$ store (Murphy and Miller, 1988). Three potential 
A

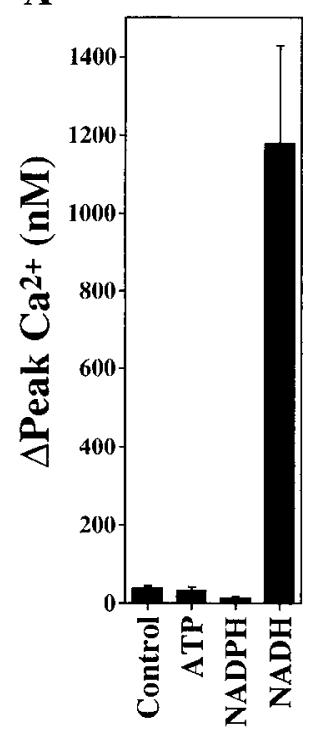

B

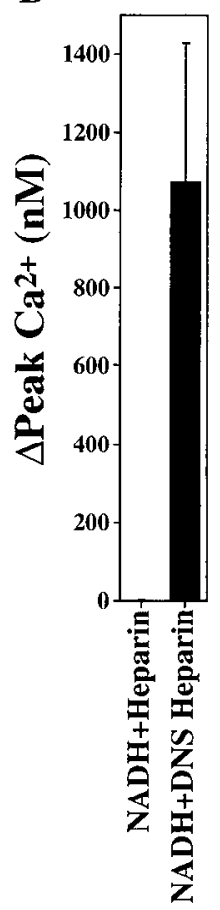

Figure 6. NADH mobilizes intracellular $\mathrm{Ca}^{2+}$ via $\mathrm{IP}_{3} \mathrm{R}$ activation. $A$, PC12 cells were loaded with Fura-2/AM, and after washout of unincorporated dye, cells were internally perfused using a pipette containing either no drug $(n=5), 4 \mathrm{mM}$ ATP $(n=6), 100 \mu \mathrm{M}$ NADPH $(n=6)$, or $100 \mu \mathrm{M}$ NADH $(n=7)$. Values represent the peak $\left[\mathrm{Ca}^{2+}\right]$ achieved during a 4-8 min monitoring period. $B$, To determine whether the $\mathrm{Ca}^{2+}$ mobilization produced by internal perfusion with $\mathrm{NADH}$ was mediated by $I_{3} \mathrm{R}$, a protocol was used in which cells were loaded with a pipette containing heparin $(100 \mu \mathrm{g} / \mathrm{ml}, n=6)$ or de- $N$-sulfated heparin (100 $\mu \mathrm{g} / \mathrm{ml}, n=4$ ) and Fura- $2, \mathrm{~K}_{5}$ salt. After removal of this pipette, and a brief recovery period, cells were repatched with a separate pipette containing NADH $(100 \mu \mathrm{M})$.

sources are the ryanodine- or $\mathrm{IP}_{3}$-sensitive endoplasmic reticular stores [both of which have been characterized in PC12 and Purkinje cells (Zacchetti et al., 1991; Reber et al., 1993)], as well as the mitochondria. Thapsigargin inhibits the $\mathrm{Ca}^{2}$-ATPase of the endoplasmic reticulum, selectively depleting $\mathrm{Ca}^{2+}$ from both $\mathrm{IP}_{3^{-}}$ and ryanodine-sensitive stores (Thastrup et al., 1990). Bath application of thapsigargin to PC12 cells abolishes the cyanide-induced release of $\mathrm{Ca}^{2+}$ (Fig. $5 A$ ), thereby ruling out mitochondria as a potential source. Ruthenium red at high nanomolar to low micromolar concentrations blocks release of $\mathrm{Ca}^{2+}$ by ryanodine receptors, leaving $\mathrm{IP}_{3} \mathrm{R}$ functionally intact (Ma, 1993). Intracellular perfusion with $10 \mu \mathrm{M}$ ruthenium red results in $\mathrm{Ca}^{2+}$ mobilization by cyanide that is indistinguishable from control conditions (Fig. $5 A$ ), suggesting that ryanodine receptors are not stimulated under these hypoxic conditions.

Heparin competitively inhibits the binding of $\mathrm{IP}_{3}$ to its receptor, thereby blocking $\mathrm{IP}_{3}$-induced $\mathrm{Ca}^{2+}$ relcasc (Ghosh, 1988). Intracellular perfusion with heparin $(100 \mu \mathrm{g} / \mathrm{ml})$ abolishes cyanideinduced $\mathrm{Ca}^{21}$ release from both PC12 (Fig. 5A) and Purkinje cells (Fig. $5 B$ ). De- $N$-sulfated heparin, which is structurally similar to heparin but does not inhibit $\mathrm{IP}_{3} \mathrm{R}$ activity (Yamamoto et al., 1990; Thorn and Petersen, 1993), fails to inhibit cyanide-induced mobilization of $\mathrm{Ca}^{2+}$ from both PC12 and Purkinje cells (Figs. 5A, 6B), suggesting that the effects of heparin are specific. Caffeine is a selective agonist of ryanodine receptors with an $\mathrm{EC}_{50}$ of $13 \mathrm{~mm}$ in

PC12 cells (Barry and Cheek, 1994). Micropressure application of caffeine $(20 \mathrm{~mm}, 10 \mathrm{sec})$ produces an increase of $\mathrm{Ca}^{2+}$ comparable in magnitude to that elicited by cyanide (Fig. $5 A$ ). Heparin (100 $\mu \mathrm{g} / \mathrm{ml})$ perfusion of cells does not affect the increase in $\mathrm{Ca}^{2+}$ evoked by caffeine (Fig. $5 A$ ), indicating specificity for the inhibition of cyanide-induced $\mathrm{Ca}^{2+}$ release by heparin. Taken together, these data suggest that cyanide-mediated hypoxia selectively mobilizes $\mathrm{Ca}^{2+}$ from $\mathrm{IP}_{3} \mathrm{R}$ stores.

Cyanide might mobilize $\mathrm{Ca}^{2+}$ by stimulating phospholipase $\mathrm{C}$ to produce $\mathrm{IP}_{3}$, although decreases in the levels of $\mathrm{IP}_{3}$ occur after hypoxia in situ (Kapuscinski, 1993; Matsumoto, 1994) and cyanide treatment of cells in culture (Kiang and Smallridge, 1994). We evaluated effects of U73122, a selective phospholipase-C inhibitor with an $\mathrm{IC}_{50}$ of $200 \mathrm{nM}$ in neuronal cells that abolishes $\mathrm{IP}_{3}$ production at $1 \mu \mathrm{M}$ (Jin ct al., 1994). Treatment with $5 \mu \mathrm{M}$ U73122 fails to block cyanide-induced elevation of $\mathrm{Ca}^{2+}{ }_{i}$ (Fig. 5A), suggesting that the cyanide effect does not require $\mathrm{IP}_{3}$ synthesis.

How might hypoxia stimulate $\mathrm{Ca}^{2+}$ release from $\mathrm{IP}_{3}$-sensitive stores? Hypoxia is manifested initially as an inhibition of mitochondrial metabolism, whereas $\mathrm{IP}_{3} \mathrm{Rs}$ reside in the cytoplasm. One of the early cytoplasmic compensatory responses to hypoxia is a stimulation of glycolysis, the Pasteur effect, which provides a means for energy production under anacrobic conditions (Krebs, 1972). This phenomena has been characterized in numerous contexts, including hypoxic human brains (Meyer et al., 1969) and neuronal cell cultures exposed to inhibitors of mitochondrial respiration (Pauwels et al., 1985). We decided to block glycolysis to ascertain whether this response to hypoxia plays a role in the stimulation of $\mathrm{IP}_{3} \mathrm{R}$ activity.

2-Deoxyglucose (2DG), an analog of glucose, is taken up by cells and phosphorylated by hexokinase in the same manncr as glucose. Unlike glucose 6-phosphate, however, phosphorylated deoxyglucose cannot be metabolized further (Siesjo, 1978). Thus, 2DG is a highly specific inhibitor of glycolysis (Bachelard, 1972). Substitution of $2 \mathrm{DG}$ for glucose abolishes cyanide-induced $\mathrm{Ca}^{2+}$ release (Fig. 5A). An alternative method for interrupting glycolysis involves inhibiting glyceraldehyde-3-phosphate dehydrogenase (GAPDH), which functions to generate NADH during the cytoplasmic catabolism of glucose. Iodoacetate is an irreversible GAPDH inhibitor, reacting with the sulfhydryl group of an essential cysteine residue at the catalytic site of the enzyme (Malhotra et al., 1993). Koningic (or heptelidic) acid, a sesquiterpene antibiotic, acts similarly to inhibit GAPDH, but is considerably more potent and selective (Kato et al., 1992). Bath application of iodoacetate to PC12 cells $(500 \mu \mathrm{M})$ or perfusion of either $\mathrm{PCl} 2$ cells or Purkinje cells with koningic acid $(50 \mu \mathrm{M})$ eliminates cyanide-induced mobilization of $\mathrm{Ca}^{2+}$ (Fig. 5A,B). Thus, stimulation of glycolysis is necessary to mediate the effects of hypoxia on $\mathrm{IP}_{3} \mathrm{R}$ activity.

Which product of glycolysis might account for the cyanideinduced $\mathrm{Ca}^{2+}$ release? Glycolysis leads to the net accumulation of NADH, ATP, and pyruvate, which is converted to lactate under hypoxic conditions. Pyruvate has no direct effect on the $\mathrm{IP}_{3^{-}}$ mediated $\mathrm{Ca}^{2+}$ flux of purified $\mathrm{IP}_{3} \mathrm{RV}[0.1 \mathrm{~mm}, 1 \mathrm{~mm}$, or $10 \mathrm{~mm}$ sodium pyruvate in the presence of $1 \mu \mathrm{M} \mathrm{IP}{ }_{3}$ results in specific $\mathrm{Ca}^{2+}$ flux that is $98 \pm 3 \%$ (mean $\pm \mathrm{SEM}, n=3$ ), $99 \pm 2 \%$, or 93 $\pm 2 \%$ of flux obtained in the absence of pyruvate, respectively]. Physiologically relevant concentrations of lactate also have no effect on $\mathrm{Ca}^{2+}$ flux of $\mathrm{IP}_{3} \mathrm{RV}[0.1 \mathrm{~mm}, 1 \mathrm{~mm}$, or $10 \mathrm{~mm}$ sodium lactate in the presence of $1 \mu \mathrm{M} \mathrm{IP}_{3}$ results in specific $\mathrm{Ca}^{2+}$ flux that is $99 \pm 0.4 \%$ (mean $\pm \mathrm{SEM}, n=3$ ), $100 \pm 2 \%$, or $97 \pm 3 \%$, respectively, of flux obtained in the absence of lactate]. 
Both NADH and ATP can stimulate activity of $\mathrm{IP}_{3} \mathrm{RV}$, although they differ in their concentration-response profiles. To examine directly the effects of these nucleotides on intact cells, we loaded PC12 cells with Fura-2/AM and then perfused them internally with test nucleotides (Fig. $6 A$ ). NADH $(100 \mu \mathrm{M})$ produces a dramatic increase in $\mathrm{Ca}^{\text {?+ }}{ }_{\text {in }}$, increasing peak $\mathrm{Ca}^{\text {p+ }}$ levels by almost $1200 \mathrm{~nm}$, resulting in approximately sixfold greater enhancement than observed in PC12 cells treated with cyanide. The increase in $\mathrm{Ca}^{2+}$ i elicited by NADH perfusion of $\mathrm{PC} 12$ cells continues into the nonlinear reporting range for Fura-2, so that the absolute increase in $\mathrm{Ca}^{2+}$ attained may be substantially greater than 1200 nM. NADPH $(100 \mu \mathrm{M})$ does not mobilize $\mathrm{Ca}^{2+}$, demonstrating that the $\mathrm{Ca}^{2}$ response to NADH is specific and not attributable to indirect effects on the cytoplasmic redox potential. Additionally, internal perfusion with ATP (4 mm) has no influence on $\mathrm{Ca}^{2+}$, suggesting that glycolytically derived ATP does not mediate $I P_{3} R$ stimulation during hypoxia. Loading of the cells with heparin (but not de- $N$-sulfated heparin) before internal perfusion with NADH blocks the subsequent $\mathrm{Ca}^{2+}$ release, further implicating $\mathrm{IP}_{3} \mathrm{R}$ stores as the source of the mobilized $\mathrm{Ca}^{2+}$ (Fig. 6B).

\section{DISCUSSION}

The main findings of this study are that NADH selectively increases $\mathrm{IP}_{3} \mathrm{R}$-mediated $\mathrm{Ca}^{2+}$ flux in purified and reconstituted receptor preparations, and that this effect seems to mediate hypoxia-induced $\mathrm{Ca}^{2+}$ release in intact cells. The demonstration here that $\mathrm{IP}_{3} \mathrm{Rs}$ are metabolically stimulated in the absence of increases in $\left[\mathrm{IP}_{3}\right]$ represents the first demonstration of physiological receptor activation in the absence of phosphoinositide hydrolysis. This mode of regulation has important implications for both normal and pathological cellular regulation.

\section{Characteristics of the stimulation of $\mathrm{IP}_{3} \mathrm{R}$ by NADH}

NADH and ATP stimulate the $\mathrm{Ca}^{2+}$ channel activity of purified and reconstituted $\mathrm{IP}_{3} \mathrm{R}$ at all $\left[\mathrm{IP}_{3}\right]$, and they seem to be acting at the same site because their effects are not additive. Because neither nucleotide affects the $K_{\mathrm{d}}$ or $B_{\text {max }}$ of $\mathrm{IP}_{3} \mathrm{R}$-binding, alterations in affinity of the receptor for its ligand or recruitment of inactive receptor-binding sites do not account for NADH and ATP actions. Instead, NADH and ATP presumably increase the efficiency of coupling between ligand binding and channel opening, consistent with the localization of all suspected nucleotidebinding sites between the $\mathrm{IP}_{3}$-binding site and the $\mathrm{Ca}^{2+}$ channel domain of $I_{3} R$ (Ferris and Snyder, 1992).

The activation of $\mathrm{IP}_{3} \mathrm{R}$-mediated $\mathrm{Ca}^{2+}$ flux by NADH is strikingly selective: NADH is four times more potent than NAD and produces a fivefold greater maximal effect. NADH is a dinucleotide composed of nicotinamide and adenine nucleotide moeities. Selectivity for NADH over NAD demonstrates that $\mathrm{IP}_{3} \mathrm{Rs}$ recognize the nicotinamide moeity, where the hydride residue that differentiates the two species resides, in addition to the adenine nucleotide moeity recognized in ATP. Surprisingly, NADP and NADPH inhibit $\mathrm{IP}_{3}$-mediated $\mathrm{Ca}^{2+}$ flux, with NADPH displaying the greatest inhibitory potency and efficacy. What might account for this inhibition? A recently discovered $\mathrm{IP}_{3} \mathrm{R}$ agonist called adenophostin $A$, the core structure of which contains an adenine nucleoside analog with a 2 '-phosphate, potently competes with $\left[{ }^{3} \mathrm{H}\right] \mathrm{IP}_{3}$ for binding to the $\mathrm{IP}_{3} \mathrm{R}\left(K_{\mathrm{i}}=0.18 \mathrm{nM}\right)$. Removal of the 2 -phosphate results in a 1000 -fold reduction in binding affinity to the IP ${ }_{3} R$ (Takahashi et al., 1994). Because NADPH/NADP differ from NADH/NAD only by the presence of a 2'-phosphate on the ribose ring of their adenine nucleotide moiety, the inhibitory effects of NADPH/NADP may reflect competition with $\mathrm{IP}_{3}$ for binding to $\mathrm{IP}_{3} \mathrm{R}$. Consistent with this proposal, increasing concentrations of $\mathrm{IP}_{3}$ overcome the inhibitory effects of NADPH and NADP on $\mathrm{IP}_{3}$-mediated $\mathrm{Ca}^{2+}$ flux (data not shown).

From the perspective of cellular energy dynamics, NADH and ATP are the two most important cellular metabolites. IP 3 RV responsiveness to both NADH and ATP suggests that under physiological conditions, $\mathrm{IP}_{3} \mathrm{R}$ activity may be linked to changes in the energy status of the cell. Several characteristics of the stimulation of $\mathrm{IP}_{3} \mathrm{R}$ by nucleotides demonstrates that the receptor is ideally suited to respond to such changes. First, the stimulatory effects of NADH and ATP on $\mathrm{IP}_{3} \mathrm{R}$ activity do not desensitize (data not shown), suggesting that $\mathrm{IP}_{3} \mathrm{R}$ can respond continuously to changes in the cytoplasmic levels of these nucleotides. Second, in the continued presence of a fixed concentration of $\mathrm{IP}_{3}$, which approximates intracellular conditions, addition of NADH or ATP stimulates $\mathrm{IP}_{3} \mathrm{R}$ activity (Table 1 ). This suggests that changing levels of these nucleotides could alter $\mathrm{Ca}^{2+}{ }_{i}$ in the absence of increases in $\left[\mathrm{IP}_{3}\right]$.

\section{Hypoxia mobilizes $\mathrm{Ca}^{2+}$ from intracellular stores}

There are several interesting aspects to the spatiotemporal pattern of cyanide-induced $\mathrm{Ca}^{2}$ mobilization. First, the response is strongly directional. It originates on the side of the cell nearest the cyanide-containing micropressure pipette and usually spreads across the cell in a decremental manner, resulting in the temporary establishment of a gradient of $\mathrm{Ca}^{2+}{ }_{i}$. In some cases, this gradient is transient and $\mathrm{Ca}^{2+}$ concentrations become equally elevated across the cell. Second, in cells bearing neurites, $\mathrm{Ca}^{2+}$ responses typically originate in the neurites and then invade the soma. This spatial pattern of response is supcrimposed on the pipette gradient such that in these cells, the earliest and most dramatic responses are seen in neurites close to the pipette.

A recent report has characterized the $\mathrm{Ca}^{2+}$ waves in NGFdifferentiated PC12 cells that are elicited by bath application of bradykinin, a phospholipase $\mathrm{C}$-coupled receptor, in a $\mathrm{Ca}^{2+}$-free medium (Lorenzon et al., 1995). These $\mathrm{Ca}^{2+}$ waves, which result from activation of $\mathrm{IP}_{3}$-sensitive $\mathrm{Ca}^{2+}$ stores, are strikingly similar to the waves elicited by treating NGF-differentiated PC12 cells with sodium cyanide (Fig. $3 B$ ). In the case of both bradykinin and cyanide, (1) $\mathrm{Ca}^{2+}$ waves originate in the neurites and subsequently invade the soma, (2) the mode of transmission of the waves is tide propagation, where there is no decline in $\mathrm{Ca}^{2+}$ levels behind the leading edge, and (3) the time course of the evolution of the waves, from high $\mathrm{Ca}^{21}$ levels in some neurites to invasion of the soma and the rest of the cell, transpires over $\sim 1$ min.

Although similar qualitatively, the $\mathrm{Ca}^{2+}$ response to hypoxia in PC12 cells and Purkinje cells differed greatly in magnitude. In fact, because the peak $\mathrm{Ca}^{2+}{ }_{\mathrm{i}}$ response of Purkinje cells to hypoxia shown in Figure $5 B$ falls into the nonlinear reporting range for Fura-2, it is likely that the difference in the responses of the two cells shown in Figure 5 are underestimated. Purkinje cells possess one of the highest concentrations of $I P_{3} R$ of any cell yet tested (20 $\mathrm{pmol} / \mathrm{mg}$ ), as assessed by $\left[{ }^{3} \mathrm{H}\right] \mathrm{IP}_{3}$-binding analysis (Worley el al., 1987). Thus, one potential source of the different $\mathrm{Ca}^{2+}$ responses of PC.12 cells and Purkinje cells to hypoxia relates to the size of their respective stores. An alternative source of this discrepancy relates to the different methods used with each cell type. After the PC12 cells were loaded with Fura-2, the electrode was retracted, and the cells were allowed to reseal and recover for $20 \mathrm{~min}$ before cyanide application. Because of their fragility, Purkinje cells were challenged with cyanide after perfusion with Fura-2, with the 
loading electrodes still attached. Because of the prolonged perfusion by the loading electrode, the Purkinje cells may have lost some cytoplasmic constituents that aided in buffering $\mathrm{Ca}^{2+}{ }_{i}$. Substantial portions of cytoplasmic constituents were retained in these cells, however, as evidenced by the fact that koningic acid blocked the cyanide-induced $\mathrm{Ca}^{2+}$ response, demonstrating that a functional glycolytic pathway was maintained in the cells that responded.

\section{Hypoxia leads to enhanced glycolytic formation of NADH, which stimulates $I_{3} \mathbf{R}$ to release $\mathrm{Ca}^{2+}$}

We identified $\mathrm{IP}_{3} \mathrm{R}$ activation as the source of the $\mathrm{Ca}^{2+}$ mobilized by hypoxia (Fig. $5 A$ ). Moreover, it seems that hypoxia-induced $\mathrm{Ca}^{2+}$ mobilization from $\mathrm{IP}_{3} \mathrm{R}$ stores takes place in the absence of increases in $\left[\mathrm{IP}_{3}\right]$. How then is hypoxia linked to $\mathrm{IP}_{3} \mathrm{R}$ activation? As a consequence of the metabolic coupling between mitochondrial respiration and glucose metabolism, hypoxia stimulates glycolysis in various tissues and organisms (Krebs, 1972). Inhibition of glycolysis blocks hypoxia-induced mobilization of $\mathrm{Ca}^{2+}$ (Fig. $5 A$ ). Glycolysis provides a crucial source of energy under hypoxic circumstances, especially in ncurons (Siesjo, 1978). If hypoxia caused mobilization of $\mathrm{Ca}^{2+}$ as a result of a passive leak generated by energy depletion, inhibition of glycolysis would be expected to exacerbate this process. The finding that glycolytic flux is necessary to facilitate hypoxia-induced $\mathrm{Ca}^{2+}$ release highlights the active nature of the stimulus for hypoxic mobilization of $\mathrm{IP}_{3}$ sensitive $\mathrm{Ca}^{2+}$ stores. In addition, anaerobic glycolysis acidifies the cytoplasm (Cervos-Navarro and Diemer, 1991), and $\mathrm{IP}_{3} \mathrm{Rs}$ are known to be inhibited by decreasing $\mathrm{pH}$ levels (Worley et al., 1987). The activation of $\mathrm{Ca}^{2+}$ release from $\mathrm{IP}_{3} \mathrm{R}$ stores under these conditions again underscores the existence of an active signalling process.

Glycolysis leads to the net accumulation of NADH, ATP, and pyruvate, which can be converted to lactate under anaerobic conditions. Unlike NADH and ATP, neither pyruvate nor lactate has any effect on $\mathrm{Ca}^{2+}$ flux of $\mathrm{IP}_{3} \mathrm{RV}$. ATP maximally stimulates $\mathrm{IP}_{3} \mathrm{R}$-mediated $\mathrm{Ca}^{2+}$ flux at $50 \mu \mathrm{M}$, with decreasing effects at higher [ATP] (Fig. 1A). Because tissue cytoplasmic [ATP] ranges from 2 to $8 \mathrm{mM}$, with values of $2.6 \mathrm{~mm}$ measured in rat brain (Veech et al., 1979), declines in normal ATP levels should stimulate $\mathrm{Ca}^{2+}$ release by $I_{3} R$. This suggests that increases in ATP as a result of glycolytic flux would not stimulate $I P_{3} R$ until cells became dramatically energy-depleted (e.g., to $<2 \%$ of normal levels in the brain). A previous report on PC12 cells exposed to 10 mM cyanide for 2.5 min showed a $30 \%$ reduction in ATP (Maduh et al., 1991). Under the conditions used in our experiments, $2 \mathrm{mM}$ cyanide for $10 \mathrm{sec}$, it is highly unlikely that cellular ATP levels would be significantly affected. Moreover, mice exposed to profound hypoxia (close to the threshold for survival) for up to $30 \mathrm{~min}$ did not show changes in brain levels of ATP, primarily as a result of increased glycolysis (Duffy et al., 1972). To test the potential role of ATP directly, we perfused PC12 cells with supraphysiological levels of ATP and found no increase in $\mathrm{Ca}^{2+}{ }_{i}$ (Fig. 6A). It seems, therefore, that ATP generated during glycolysis does not mediate hypoxic stimulation of $\mathrm{IP}_{3} \mathrm{R}$ activity.

The concentration-response relationship for NADH, which is normally present in low micromolar concentrations in the cytoplasm (Sies, 1982), suggests that increases in NADH derived from glycolysis would stimulate $\mathbf{I P}_{3} \mathrm{R}$ activity (Fig. 2). Increases in PC12 cell cytoplasmic NADH levels are sufficient to dramatically mobilize $\mathrm{Ca}^{2+}$ from intracellular stores (Fig. 6A). Inhibition of the effects of NADH by heparin, but not de- $N$-sulfated heparin, further implicates $\mathrm{IP}_{3} \mathrm{R}$ in this $\mathrm{Ca}^{2+}$-release process (Fig. $6 B$ ). Taken together, our data suggest that NADH generated as a result of enhanced glycolytic flux under hypoxic conditions leads to a stimulation of $\mathrm{IP}_{3} \mathrm{R}$ activity resulting in increases in $\mathrm{Ca}^{2+}{ }_{i}$.

\section{Functional significance of hypoxia-induced activation of $I P_{3} R$}

In Purkinje cells, stacked endoplasmic reticulum cisternae highly enriched in $\mathrm{IP}_{3} \mathrm{R}$ lie closely apposed to mitochondria (Mignery et al., 1989). In HeLa cells, $\mathrm{IP}_{3} \mathrm{R}$ activation releases $\mathrm{Ca}^{2+}$ in close proximity to mitochondria, markedly elevating mitochondrial matrix $\mathrm{Ca}^{2+}$ levels (Rizzuto et al., 1993). This matrix $\mathrm{Ca}^{2+}$ enhances the production of ATP through oxidative phosphorylation, presumably by stimulating diverse processes that include NAD-linked dchydrogenase, ATP synthase and adenine nucleotide transporter activities, and electron transport (McCormack et al., 1990); Gunter et al., 1994). In this way, activation of $I P_{3} R$ activity by glycolytic $\mathrm{NADH}$ could represent an attempt to stimulate energy production during hypoxic inhibition of mitochondrial respiration. This augmentation of mitochondrial function may also provide energy to fuel the diverse cellular processes stimulated by physiological signal transduction involving $\mathrm{IP}_{3}$.

Some CNS ncurons, such as cortical and hippocampal CAI pyramidal neurons, become hyperpolarized during hypoxia. This decreases their probability of firing and results in an inhibition of excitatory synaptic transmission, perhaps to conserve energy and avoid excitotoxicity (Somjen et al., 1993). The hyperpolarization results from stimulation of $\mathrm{Ca}^{2+}$-activated potassium channels, which seem to be responding predominantly to $\mathrm{Ca}^{2+}$ released by $\mathrm{IP}_{3} \mathrm{R}$ (Leblond and Krnjevic, 1989; Latha et al., 1994; Belousov et al., 1995). Thus, in addition to augmenting energy production, hypoxic stimulation of $\mathrm{IP}_{3} \mathrm{R}$ activity may lead to energy preservation in some cells.

\section{Pathological significance of hypoxia-induced $\mathbf{I P}_{\mathbf{3}} \mathbf{R}$ activation}

Our studies and a recent study using $\mathrm{N}_{2}$ aeration to induce hypoxia in hippocampal slices (Belousov et al., 1995) implicate $\mathrm{IP}_{3} \mathrm{R}$ in $\mathrm{Ca}^{2+}$ released by hypoxia. $\mathrm{Ca}^{2+}$ influx may also contribute to hypoxia-induced increases in $\mathrm{Ca}^{2+}$, because placing cells in a $\mathrm{Ca}^{2+}$-free solution resulted in a partial decrease in the levels of $\mathrm{Ca}^{2+}{ }_{i}$ that were obtained (Krnjevic and $\mathrm{Xu}, 1989$; Biscoe and Duchen, 1990; Duchen et al., 1990; Hasham et al., 1994; Latha et al., 1994). Numerous examples exist in which mobilization of $\mathrm{Ca}^{2+}$ from $\mathrm{IP}_{3}$-sensitive stores subsequently leads to $\mathrm{Ca}^{2+-}$ influx (Irvine, 1992; Fasolato et al., 1994).

Some reports indicate that hypoxia-induced increases in $\mathrm{Ca}^{2+}{ }_{i}$ are a relatively late phenomenon that occurs minutes to hours after the initiation of hypoxia (Arnould et al., 1992; Kiang and Smallridge, 1994; Ray et al., 1994). These reports suggest that increases in $\mathrm{Ca}^{2+}{ }_{i}$ result primarily from $\mathrm{Ca}^{2}{ }^{+}$influx (Arnould et al., 1992; Kiang and Smallridge, 1994) or inhibition of the endoplasmic reticular $\mathrm{Ca}^{2+}$ pump (Ray et al., 1994). These experiments, however, were performed in the absence of glucose (Arnould et al., 1992; Kiang and Smallridge, 1994) or in the presence of 2DG (Ray et al., 1994), conditions that prevent the glycolytic formation of NADH. This experimental paradigm, in which hypoxia is induced while glycolysis is inhibited, is believed to model conditions found after the interruption of blood supply in ischemic hypoxia. Under physiological conditions, however, the brain maintains a glycogen reserve that becomes rapidly depleted after the cessation of blood flow (Siesjo, 1978). Increases in tissue 
lactate concentrations occur after the induction of ischemic hypoxia in animals, indicating an increase in anaerobic glycolysis (Palmer et al., 1990). Thus, although the induction of hypoxia in the absence of glucose may adequately reflect the metabolic conditions to which neurons are exposed relatively late in ischemic hypoxia, they do not seem to reflect the conditions encountered during the early moments after the cessation of $\mathrm{O}_{2}$ supply. It is during this initial period that we have demonstrated activation of $I P_{3} R$ activity by hypoxia.

The precise mechanisms by which hypoxia results in cell death and certain cells such as neurons are rendered particularly vulnerable to hypoxic injury are not known in detail. It is widely believed, however, that $\mathrm{Ca}^{21}$ plays a central role in these processes, perhaps serving as the trigger for a series of reactions that culminate in cellular demise (Schanne et al., 1979; Sicsjo, 1981). The current model for hypoxia-mediated increases in $\mathrm{Ca}^{2+}$, maintains that reduced $\mathrm{O}_{2}$ levels lead to depletion of energy stores and result in an inability to sequester $\mathrm{Ca}^{2+}$ (Somjen et al., 1993). Irreversible neuronal injury can occur in the absence of ATP depletion (Cervos-Navarro and Diemer, 1991), however, and our work demonstrates that hypoxia mobilizes $\mathrm{Ca}^{2}$ in an active process that does not involve inhibition of $\mathrm{Ca}^{\text {p+ }}$ sequestration. Interestingly, the distribution of neurons in the brain that are most vulnerable to hypoxic injury (Siesjo, 1981; Kuroiwa and Okeda, 1994) corresponds with regions of greatest $\mathrm{IP}_{3} \mathrm{R}$ density (Worley et al., 1989; Nakanishi et al., 1991; Sharp et al., 1993; Suburo et al., 1993), such as cerebellar Purkinje cells, pyramidal neurons in the CA1 region of the hippocampus, layers III, V, and VI of the cortex, and small- and medium-sized striatal neurons.

We have used purified and reconstituted $\mathrm{IP}_{3} \mathrm{R}$, NGF-treated PC12 cells, and cerebellar Purkinje neurons to demonstrate that within seconds after the induction of hypoxia, $\mathrm{Ca}^{2+}$ is mobilized from intracellular stores as the result of NADH-mediated stimulation of $\mathrm{IP}_{3} \mathrm{R}$ channel activity. Further studies should help elucidate whether this $\mathrm{Ca}^{2+}$ acts as a messenger, perhaps serving to help regulate metabolism, or as a trigger of subsequent deleterious events.

\section{REFERENCES}

Albaum HG, Tepperman J, Bodansky O (1946) The in vivo inactivation by cyanide of brain cytochrome oxidase and its effect on glycolysis and on the high energy phosphorus compounds in the brain. J Biol Chem 164:45-51.

Arnould T, Michicls C, Alexandre I, Remacle J (1992) Effect of hypoxia upon intracellular calcium concentration of human endothelial cells. J Cell Physiol 152:215-212.

Bachelard HS (1972) Deoxyglucose and brain glycolysis. Biochem J 127:83P.

Barry VA, Cheek TR (1994) A caffeine- and ryanodine-sensitive intracellular $\mathrm{Ca}^{2+}$ store can act as a $\mathrm{Ca}^{2+}$ source and a $\mathrm{Ca}^{2+}$ sink in $\mathrm{PC1} 2$ cells. Biochem J 300:589-597.

Becker GL, Fiskum G, Lehninger AL (1980) Regulation of free $\mathrm{Ca}^{2+}$ by liver mitochondria and endoplasmic reticulum. $\mathbf{J}$ Biol Chem 255:9009-9012.

Belousov A, Godfraind JM, Krnjevic K (1995) Inernal $\mathrm{Ca}^{21}$ stores involved in anoxic responses of rat hippocampal neurons. J Physiol 486:547-556.

Berridge MJ (1993) Inositol trisphosphate and calcium signalling. Nature $361: 315-325$

Bezprozvanny I, Ehrlich BE (1993) ATP modulates the function of inositol 1,4,5-trisphosphate-gated channels at two sites. Ncuron 10:1175-1184.

Biscoe TJ, Duchen MR (1990) Responses of type I cells dissociated from the rabbit carotid body to hypoxia. J Physiol 428:39-59.

Bredt DS, Mourey RJ, Snyder SH (1989) A simple, sensitive, and specific radioreceptor assay for inositol 1,4,5-trisphosphate in biological tissues. Biochem Biophys Res Commun 159:976-982.
Cervos-Navarro J, Diemer NH (1991) Selective vulnerability in brain hypoxia. Crit Rev Neurobiol 6:149-182.

Dubinsky JM, Rothman SM (1991) Intracellular calcium concentrations during "chemical hypoxia" and excitotoxic neuronal injury. J Neurosci 11:2545-2551.

Duchen MR, Peuchen S, Nowicky A (1993) Changes in mitochondrial function in response to changes in cytosolic $\mathrm{Ca}^{2}$ concentration. Biomed Res 14:139-146.

Duchen MR, Valdeolmillos M, O'Neill SC, Eisner DA (1990) Effects of metabolic blockade on the regulation of intracellular calcium in dissociated mouse sensory neurons. J Physiol 424:411-426.

Duffy TE, Nelson SR, Lowry OH (1972) Cerebral carbohydrate metabolism during acute hypoxia and recovery. J Neurochem 19:959-977.

Fasolato C, Innocenti B, Pozzan, T (1994) Receptor-activated $\mathrm{Ca}^{2+}$ influx: how many mechanisms for how many channels? Trends Pharmacol Sci 15:77-83.

Ferris CD, Cameron AM, Huganir RL, Snyder SH (1992) Quantal calcium release by purified reconstituted inositol 1,4,5-trisphosphate receptors. Nature 356:350-352.

Ferris CD, Huganir RL, Snyder SH (1990) Calcium flux mediated by purified inositol 1,4,5-trisphosphate receptor in reconstituted lipid vesicles is allosterically regulated by adenine nucleotides. Proc Natl Acad Sci USA 87:2147-2151.

Ferris CD, Huganir RL, Supattapone S, Snyder SH (1989) Purified inositol 1,4,5-trisphosphate receptor mediates calcium flux in reconstituted lipid vesicles. Nature 342:87-89.

Ferris CD, Snyder SH (1992) Inositol 1,4,5-trisphosphalt-activated calcium channels. Annu Rev Physiol 54:469-488.

Ghosh TK, Eis PS, Mullaney JM, Ebert CL, Gill DL (1988) Competitive, reversible, and potent antagonism of inositol 1,4,5-trisphosphateactivated calcium release by heparin. J Biol Chem 263:11075-1 1079 .

Grynkiewicz G, Poenie M, Tsien RY (1985) A new generation of $\mathrm{Ca}^{2+}$ indicators with greatly improved fluorescence properties. J Biol Chem 260:3440-3450.

Gunter TE, Gunter KK, Sheu SS, Gavin CE (1994) Mitochondrial calcium transport: physiological and pathological relevance. Am J Physiol 267:C313-C339.

Hasham MI, Naumann D, Kim SU, Cashman NR, Quamme GA, Krieger C (1994) Intracellular calcium concentrations during metabolic inhibition in the motoneuron cell line NSC-19. Can J Physiol Pharmacol 72:728-737.

Ino $M$ (1991) Effects of adenine nucleotides on inositol 1,4,5trisphosphate-induced calcium release in vascular smooth muscle cells. J Gen Physiol 98:681-698.

Irvine RF (1992) Inositol phosphates and $\mathrm{Ca}^{2+}$ entry: toward a proliferation or a simplification? FASEB J 6:3085-3091.

Jin W, Lo TM, Loh HH, Thayer SA (1994) U73122 inhibits phospholipase C-dependent calcium mobilization in neuronal cells. Brain Res 642:237-243.

Kapuscinski A (1993) Effect of clinical death on inositol 1,4,5trisphosphate in the rat brain. Neuropatol Pol 31:91-96.

Kato M, Sakai K, Endo A (1992) Koningic acid (heptelidic acid) inhibition of glyceraldehyde-3-phosphate dehydrogenases from various sources. Biochim Biophys Acta 1120:113-116.

Kiang JG, Smallridge RC (1994) Sodium cyanide increases cytosolic free calcium: evidence for activation of the reversed mode of the $\mathrm{Na}^{+} / \mathrm{Ca}^{2+}$ exchanger and $\mathrm{Ca}^{2+}$ mobilization from inositol trisphosphateinsensitive pools. Toxicol Appl Pharmacol 127:173-181.

Krebs HA (1972) The Pasteur effect and the relations between respiration and fermentation. Essays Biochem 8:1-34.

Krnjevic K, Xu YZ (1989) Dantrolene suppresses the hyperpolarization or outward current observed during anoxia in hippocampal neurons. Can J Physiol Pharmacol 67:1602-1604.

Kuroiwa T, Okeda R (1994) Neuropathology of cerebral ischemia and hypoxia: recent advances in experimental studies on its pathogenesis. Pathol Int 44:171-181.

Lai JCK, Behar KL (1993) Glycolysis-citric acid cycle intcrrclation: a new approach and some insights in cellular and subcellular compartmentation. Dev Neurosci 15:181-193.

Latha MV, Borowitz JL, Yim GK, Kanthasamy A, Isom GE (1994) Plasma membrane hyperpolarization by cyanide in chromaffin cells: role of potassium channcls. Arch Toxicol 68:370-374.

Leblond J, Krnjevic K (1989) Hypoxic changes in hippocampal ncurons. J Neurophysiol 62:1-14. 
Linden DJ, Dickinson MH, Smeyne M, Connor JA (1991) A long-term depression of AMPA currents in cultured cerebellar Purkinje neurons. Neuron 7:81-89.

Loew LM, Carrington W, I Iuft RA, Fay FS (1994) Physiological cytosolic $\mathrm{Ca}^{2+}$ transients evoke concurrent mitochondrial depolarizations. Proc Natl Acad Sci USA 91:12579-12583.

Lorenzon P, Zacchetti D, Codazzi F, Fumagalli G, Meldolesi J, Grohovaz $\mathrm{F}$ (1995) $\mathrm{Ca}^{2+}$ waves in $\mathrm{PC1} 2$ neurites-a bidirectional, receptororiented form of $\mathrm{Ca}^{2+}$ signaling. J Cell Biol 129:797-804.

Ma J (1993) Block by ruthenium red of the ryanodine-activated calcium release channel of skeletal muscle. J Gen Physiol 102:1031-1056.

Maduh EU, Borowitz JL, Isom GE (1991) Cyanide-induced alteration of the adenylate energy pool in a rat neurosecretory cell line. J Appl Toxicol 11:97-101.

Malhotra OP, Srivastava DK, Kayastha AM, Srinivasan (1993) Inactivation of glyceraldehyde-3-phosphate dehydrogenase with SH-rcagents and its relationship to the protein quaternary structure. Int $\mathbf{J}$ Biochem Biophys 30:264-269.

Matsumoto H, Baron CB, Coburn RF (1994) Inositol trisphosphate and energy-force coupling in rabbit aorta. J Pharmacol Exp Ther 270:708-712.

McCormack JG, Halestrap AP, Denton RM (1990) Role of calcium ions in regilation of mammalian intramitochondrial metabolism. Physiol Rev 70:391-425.

Meyer JS, Ryu T, Toyoda M, Shinohara Y, Wiederholt I, Guiraud B (1969) Evidence for a Pasteur effect regulating cerebral oxygen and carbohydrate metabolism in man. Neurology 19:954-962.

Mignery GA, Sudhof TC, Takci K, De Camilli P (1989) Putative receptor for inositol 1,4,5-trisphosphate similar to ryanodine receptor. Nature 342:192-195.

Murphy SN, Miller RJ (1988) A glutamate receptor regulates $\mathrm{Ca}^{2+}$ mobilization in hippocampal neurons. Proc Natl Acad Sci USA 85:8737-8741.

Nakanishi S, Maeda N, Mikoshiba K (1991) Immunohistochemical localization of an inositol 1,4,5-trisphosphate receptor, $\mathrm{P} 400$, in neural tissue: studies in developing and adult mouse brain. $\mathbf{J}$ Neurosci 11:2075-2086.

Oraki H, Satoh T, Karaki H, Ishida Y (1988) Regulation of metabolism and contraction by cytoplasmic calcium in intestinal smooth muscle. J Biol Chem 263:14074-14079.

Palmer C, Brucklacher RM, Christensen M $\Lambda$, Vannucci RC (1990) Carbohydrate and energy metabolism during the evolution of hypoxicischemic brain damage in the immature rat. J Cereb Blood Flow Metab 10:227-235.

Pauwels PJ, Opperdoes FR, Trouet A (1985) Effects of antimycin, glucose deprivation, and serum on cultures of neurons, astrocytes, and neuroblastoma cells. J Neurochem 44:143-148.

Ray P, Ray R, Broomfield CA, Berman JD (1994) Inhibition of bioenergetics alters intracellular calcium, membrane composition, and fluidity in a neuronal cell line. Neurochem Res 19:57-63.

Reber BF, Stucki JW, Reuter H (1993) Unidirectional interaction between two intracellular calcium stores in rat phaeochromocytoma (PC12) cells. J Physiol 468:711-727.

Rizzuto R, Brini M, Murgia M, Pozzan T (1993) Microdomains with high $\mathrm{Ca}^{2+}$ close to $\mathrm{IP}_{3}$-sensitive channels that are sensed by neighboring mitochondria. Science 262:744-747.

Schanne FA, Kane AB, Young EE, Farber JL (1979) Calcium dependence of toxic cell death: a final common pathway. Science 206:700-702.
Sharp AH, Dawson TM, Ross CA, Fotuhi M, Mourey RJ, Snyder SH (1993) Inositol 1,4,5-trisphosphate receptors: immunohistochemical localization to discrete areas of rat central nervous system. Neuroscience 53:927-942.

Sheu SS, Jou MJ (1994) Mitochondrial free $\mathrm{Ca}^{2+}$ concentration in living cells. J Bioenerg Biomembr 26:487-493.

Sies H (1982) Metabolic compartmentation (Sies H, ed). New York: Academic.

Siesjo BK (1981) Cell damage in the brain: a speculative synthesis. J Cereb Blood Flow Metab 1:155-185.

Siesjo BK (1978) Brain energy metabolism, (Siesjo BK, ed), p 607. New York: Wiley.

Silver IA, Erecinska M (1990) Intracellular and extracellular changes of $\left[\mathrm{Ca}^{2+}\right]$ in hypoxia and ischemia in rat brain in vivo. $J$ Gen Physiol 95:837-866.

Somjen GG, Aitken PG, Czeh G, Jing J, Young JN (1993) Cellular physiology of hypoxia of the mammalian central nervous system. Res Publ Assoc Res Nerv Ment Dis 71:51-65.

Suburo AM, Rodrigo J, Rossi ML, Martinez-Murillo R, Terenghi G, Maeda N, Mikoshiba K, Polak JM (1993) Immunohistochemical localization of the inositol 1,4,5-trisphosphate receptor in the human nervous system. Brain Res 601:193-202.

Takahashi M, Tanzawa K, Takahashi S (1994) Adenophostins, newly discovered metabolites of Penicillium brevicompactum, act as potent agonists of the inositol 1,4,5-trisphosphate receptor. J Biol Chem 269:369-372.

Thastrup O, Cullen PJ, Drobak BK, Hanley MR, Dawson AP (1990) Thapsigargin, a tumor promoter, discharges intracellular $\mathrm{Ca}^{2+}$ stores by specific inhibition of the endoplasmic reticulum $\mathrm{Ca} 2(+)$ ATPasc. Proc Natl Acad Sci USA 87:2466-2470.

Thorn P, Petersen OH (1993) Calcium oscillations in pancrcatic acinar cells, evoked by the cholecystokinin analogue JMV-180, depend on functional inositol 1,4,5-trisphosphate receptors. J Biol Chem 268:23219-23221.

Veech RL, Lawson JW, Cornell NW, Krebs HA (1979) Cytosolic phosphorylation potential. J Biol Chem 254:6538-6547.

Veech RL, Raijman L, Krebs HA (1970) Equilibrium relations between the cytoplasmic adenine nucleotide system and nicotinamide adenine nucleotide system in rat liver. Biochem J 117:499-503.

Worley PF, Baraban JM, Snyder SH (1989) Inositol 1,4,5-trisphosphate receptor binding: autoradiographic localization in rat brain. J Neurosci 9:339 346.

Worley PF, Baraban JM, Supattapone S, Wilson VS, Snyder SH (1987) Characterization of inositol trisphosphate receptor binding in brain: regulation by $\mathrm{pH}$ and calcium. J Biol Chem 262:12132-12136.

Yager JY, Brucklacher RM, Vannucci RC (1991) Cerebral oxidative metabolism and redox state during hypoxia-ischemia and early recovery in immature rats. Am J Physiol 261:H1102-1108.

Yamamoto H, Kanaide H, Nakamura M (1990) Heparin specifically inhibits the inositol 1,4,5-trisphosphate-induced $\mathrm{Ca}^{2+}$ release from skinned rat aortic smooth muscle cells in primary culture. Naunyn Schmiedebergs Arch Pharmacol 341:273-278.

Zacchetti D, Clementi E, Fasolato C, Lorenzon P, Zottini M, Grohovaz F, Fumagalli G, Pozzan T, Meldolesi J (1991) Intracellular Ca ${ }^{2+}$ pools in PC12 cells: a unique, rapidly exchanging pool is sensitive to both inositol 1,4,5-trisphosphate and caffeine-ryanodine. J Biol Chem 266:20152-20158. 